\title{
HUBUNGAN STRATEGI PEMBERDAYAAN PETERNAK DENGAN KESEJAHTERAAN PETERNAK
} (Kasus Program Pemberdayaan Kampoeng Ternak di Koperasi Peternak Serba Usaha Riung Mukti, Kabupaten Sukabumi, Jawa Barat)

\section{The Relationship of Empowerment Strategy with Breeders Welfare}

\author{
Dwi Jayanti ${ }^{1)}$ dan Sofyan Sjaf ${ }^{1)}$ \\ ${ }^{1)}$ Departemen Sains Komunikasi dan Pengembangan Masyarakat, Fakultas Ekologi Manusia, Institut \\ Pertanian Bogor, Darmaga Bogor 16680, Indonesia \\ Email: jayanti.dwi02@gmail.com; sofyansjaf@apps.ipb.ac.id
}

\begin{abstract}
Livestock is one of the livelihoods of Indonesian communities to meet their needs. However, socioeconomic conditions of farmers face problems including low bargaining position, low education levels, the condition of scattered farms, simple technology. To overcome these problems, we need to empower breeder. Kampoeng Ternak is a network of Dompet Dhuafa who engaged in the empowerment of breeders. Empowerment process requires an effective strategy to achieve the goal. To that end, the purpose of this research is to examine the relationship of empowerment strategies to improve the welfare of farmers. The method used in this research is quantitative method with the approach of the survei and supported by qualitative methods. Respondents were determined through simple random sampling. Test the relationship will be conducted with test-Spearman Rank. The results of this research showed that there is a relationship between empowerment strategies with the welfare of farmers. Such relations are moderate. While on each pattern empowerment strategy, only strengthening group associated with the level of welfare.
\end{abstract}

Keywords: Empowerment, Empowerment Strategy, Welfare

\begin{abstract}
ABSTRAK
Peternakan rakyat merupakan salah satu mata pencaharian masyarakat Indonesia untuk memenuhi kebutuhan hidupnya. Namun, kondisi sosial ekonomi masyarakat peternak menghadapi permasalahan diantaranya posisi tawar yang rendah, tingkat pendidikan rendah, kondisi peternakan tersebar, teknologi sederhana. Untuk mengatasi permasalahan tersebut, perlu dilakukan pemberdayaan peternak rakyat (kecil). Kampoeng Ternak merupakan jejaring Dompet Dhuafa yang bergerak dalam pemberdayaan peternak. Proses pemberdayaan memerlukan strategi yang efektif untuk mencapai tujuan. Untuk itu, tujuan dari penelitian ini yaitu untuk mengkaji hubungan dari strategi pemberdayaan dengan kesejahteraan peternak. Metode yang digunakan dalam penelitian ini yaitu metode kuantitatif dengan pendekatan survai dan didukung oleh metode kualitatif. Responden ditentukan melalui simple random sampling. Uji hubungan dilakukan dengan uji Rank-Spearman. Hasil penelitian menunjukkan bahwa terdapat hubungan antara strategi pemberdayaan dengan tingkat kesejahteraan peternak. Hubungan tersebut tergolong moderat. Sedangkan pada masing-masing pola strategi pemberdayaan, hanya penguatan kelompok yang berhubungan dengan tingkat kesejahteraan.
\end{abstract}

Kata kunci: Kesejahteraan, Pemberdayaan, Strategi Pemberdayaan 


\section{PENDAHULUAN}

Masalah pokok dan isu sentral pembangunan ekonomi dan sosial yang masih terus dikaji di Indonesia adalah masalah pemberdayaan rakyat dan kemiskinan. Kemiskinan merupakan salah satu permasalahan yang selalu dihadapi Bangsa Indonesia. Jumlah penduduk miskin di Indonesia sampai pada Maret 2013 menurut Badan Pusat Statistik (2014) yaitu 28,07 juta jiwa. Sebagian besar jumlah penduduk miskin berada pada kawasan perdesaan (17,74 juta jiwa). Kawasan perdesaan identik dengan potensi pertanian yang besar sekaligus kemiskinan yang dialami masyarakat. Mayoritas masyarakat pedesaan menggantungkan hidupnya pada sektor pertanian, salah satunya termasuk subsektor peternakan.

Permasalahan yang dihadapi oleh subsektor peternakan saat ini yaitu kebutuhan konsumsi dari hewan ternak yang terus meningkat, namun produksi dalam negeri belum mampu mencukupinya, sehingga kebutuhan konsumsi tersebut dipenuhi melalui impor. Permasalahan ini disebabkan kondisi kelemahan internal yang belum diperhatikan. Usaha peternakan rakyat di Indonesia mempunyai ciri-ciri antara lain tingkat pendidikan peternak rendah, pendapatan rendah, penerapan manajemen dan teknologi konvensional, lokasi ternak menyebar luas, ukuran skala usaha relative sangat kecil serta pengadaan input utama yakni hijauan makanan ternak (HMT) yang masih tergantung pada musim, ketersediaan tenaga kerja keluarga (Yusdja dan Ilham 2006). Berdasarkan fakta tersebut, perlu dilakukan upaya dalam pengembangan peternakan.

Pengembangan peternakan harus diorientasikan pada pemberdayaan peternak. Pengembangan peternakan bertujuan untuk mencukupi kebutuhan pangan, barang, dan jasa asal hewan secara mandiri, berdaya saing, dan berkelanjutan bagi peningkatan kesejahteraan peternak dan masyarakat menuju pencapaian ketahanan pangan nasional. Untuk mencapai tujuan tersebut, salah satunya perlu dilakukan upaya pemberdayaan. Proses pemberdayaan memerlukan strategi yang efektif agar dapat tercapai tujuan dari pemberdayaan.Strategi pemberdayaan masyarakat khususnya di pedesaan dengan memanfaatkan dan mengembangkan institusi lokal dan modal sosial lokal yang berlandaskan pada aspek karakteristik sosial, budaya, agama, nilai dan etika masyarakat lingkungan sosial lokal merupakan strategi yang tepat.

Umumnya, pemberdayaan petani-peternak di pedesaan dilakukan melalui pembentukan kelompok petani-peternak. Namun, kelompok petani-peternak tersebut dibentuk dari atas(pemerintah) dan tidak dilakukan secara partisipatif serta pembentukan kelompok tidak disertai dengan peningkatan kualitas petanipeternak sehingga kelompok belum mampu mandiri dan menimbulkan ketergantungan pada petani-peternak. Selain itu, program-program pembangunan belum sepenuhnya memenuhi aspirasi, kepentingan, keinginan, harapan serta kebutuhan masyarakat, serta belum mampu memberikan manfaat kepada masyarakat secara berkelanjutan. Kampoeng Ternak Nusantara merupakan lembaga jejaring Dompet Dhuafa yang melakukan program pemberdayaan berupa pengembangan peternakan berbasis pada peternakan rakyat. Kampoeng Ternak melakukan aktivitas pemberdayaan seperti pembentukan dan pendampingan kelompok peternak, pelatihan, dan mengembangkan jejaring peternakan. Berdasarkan pemaparan tersebut, Kampoeng Ternak melakukan berbagai strategi pemberdayaan untuk mencapai tujuannya. Untuk itu, menarik untuk mengkaji hubungan strategi pemberdayaan yang diimplementasikan Kampoeng Ternak dengan kesejahteraan peternak.

Strategi diartikan sebagai cara atau kegiatan untuk mencapai suatu tujuan tertentu. Kegiatan pemberdayaan memerlukan strategi yang efektif untuk mencapai tujuan pemberdayaan. Strategi pemberdayaan yang diterapkan haruslah membangkitkan kesadaran masyarakat, menumbuhkan kemandirian dan dapat memperbaiki kesejahteraan masyarakat. Berdasarkan uraian tersebut, rumusan permasalahan dalam kajian ini yaitu sejauh mana hubungan implementasi strategi pemberdayaan terhadap kesejahteraan peternak? Untuk menjawab pertanyaan tersebut, diuraikan beberapa pertanyaan pendukung yaitu

1. Sejauh mana hubungan antara pelaksanaan strategi pemberdayaan melalui peningkatan kapasitas dengan tingkat kesejahteraan? 
2. Sejauh mana hubungan antara pelaksanaan strategi pemberdayaan melalui penguatan kelembagaan dengan tingkat kesejahteraan?

3. Sejauh mana hubungan antara pelaksanaan strategi pemberdayaan melalui pengembangan kemitraan dengan tingkat kesejahteraan?

Berdasarkan rumusan masalah penelitian di atas, dapat dirumuskan tujuan penelitian umum pada penelitian ini yaitu untuk menganalisis sejauh mana hubungan dari strategi pemberdayaan peternakan rakyat dengan tingkat kesejahteraan peternak. Adapun tujuan yang lebih spesifik lainnya adalah sebagai berikut:

1. Menganalisis sejauh mana hubungan pelaksanaan strategi pemberdayaan melalui peningkatan kapasitas dengan kesejahteraan peternak

2. Menganalisis sejauh mana hubungan pelaksanaan strategi pemberdayaan melalui penguatan kelembagaan dengan kesejahteraan peternak

3. Menganalisis sejauh mana hubungan pelaksanaan strategi pemberdayaan melalui penguatan kemitraan dengan kesejahteraan peternak

\section{PENDEKATAN TEORITIS}

\section{Konsep dan Definisi Pemberdayaan}

Istilah pemberdayaan merupakan terjemahan dari istilah "empowerment", yang secara harfiah bisa diartikan sebagai "pemberkuasaan", dalam artian pemberian atau peningkatan kekuasaan pada masyarakat yang lemah atau tidak beruntung. Kartasasmita (1996) mendefinisikan pemberdayaan sebagai upaya untuk meningkatkan harkat dan martabat lapisan masyarakat yang dalam kondisi sekarang tidak mampu melepaskan diri dari perangkap kemiskinan dan keterbelakangan. Dengan kata lain, memberdayakan adalah memampukan dan memandirikan masyarakat.

\section{Strategi Pemberdayaan}

Strategi diartikan sebagai langkah-langkah atau tindakan tertentu yang dilaksanakan demi tercapainya suatu tujuan atau penerima manfaat yang dikehendaki. Mardikanto (2010) mendefinisikan strategi dengan beragam pendekatan yaitu: (1) strategi sebagai suatu rencana; (2) strategi sebagai suatu kegiatan; (3) strategi sebagai suatu instrument; (4) strategi sebagai suatu sistem dan (5) strategi sebagai pola pikir. Dalam penelitian ini strategi didefinisikan sebagai kegiatan yang dilakukan oleh perusahaan/organisasi untuk mencapai tujuan pemberdayaan.

Parson et al (1994) dalam Suharto (2005) menyatakan bahwa proses pemberdayaan umumnya dilakukan secara kolektif. Pendekatan kolektif merupakan strategi utama dalam pemberdayaan masyarakat. Dalam konteks pekerjaan sosial, pemberdayaan dapat dilakukan melalui tiga aras atau matra pemberdayaan (empowerment setting): mikro, mezo dan makro.

Tabel 1 menunjukkan hasil elaborasi antara aras dan pola strategi pemberdayaan. Hasil tersebut menunjukkan, variabel-variabel yang digunakan untuk mengukur strategi pemberdayaan. Pada Tabel 1 menunjukkan pelaksanaan operasional dari masing-masing pola strategi pemberdayaan di masing-masing aras. Variabel strategi pemberdayaan dalam penelitian ini didefinisikan sebagai pelaksanaan kegiatan dalam program pemberdayaan peternak yang dilakukan oleh Kampoeng Ternak. Strategi pemberdayaan melalui peningkatan kapasitas bertujuan untuk menghasilkan sumber daya manusia yang unggul dan mampu secara mandiri menganalisis dan memecahkan permasalahannya sendiri. Pada strategi pemberdayaan melalui penguatan kelembagaan/kelompok bertujuan untuk meningkatkan peran dan fungsi kelembagaan dalam kehidupan masyarakat. Selama ini, kelembagaan yang dimiliki masyarakat belum mampu berperan secara maksimal, karena itu perlu dilakukan penguatan kelembagaan. Kemudian, strategi pemberdayaan melalui penguatan kemitraan dimaksudkan untuk mensinergikan kekuatan yang dimiliki oleh setiap pihak yang bermitra guna menutupi keterbatasan dan kelemahan yang dimiliki oleh setiap pihak. Untuk mengukur keefektivan dari ketiga strategi pemberdayaan tersebut dapat dilihat melalui variabel-variabel yang terdapat pada Tabel 1 . 
Tabel 1 Identifikasi aras dan pola strategi pemberdayaan

\begin{tabular}{|c|c|c|c|}
\hline \multirow{2}{*}{$\begin{array}{c}\text { Pola Strategi } \\
\text { Pemberdayaan }\end{array}$} & \multicolumn{3}{|c|}{ Aras } \\
\hline & Mikro & Mezo & Makro \\
\hline $\begin{array}{l}\text { Pengembangan } \\
\text { Kapasitas }\end{array}$ & $\begin{array}{l}\text { - Proses pembelajaran, } \\
\text { atau pelatihan, atau } \\
\text { pendidikan } \\
\text { - peningkatan } \\
\text { kesadaran } \\
\end{array}$ & $\begin{array}{l}\text { Motivasi untuk } \\
\text { berkelompok }\end{array}$ & - \\
\hline Penguatan kelembagaan & $\begin{array}{l}\text { Pengembangan } \\
\text { pengetahuan tentang } \\
\text { kelompok }\end{array}$ & 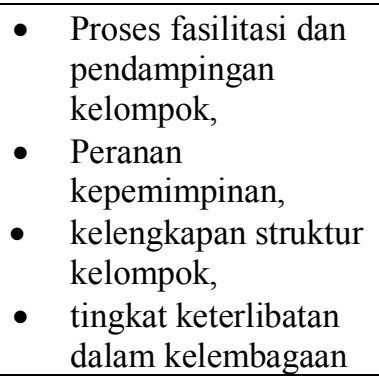 & $\begin{array}{l}\text { Jaringan sosial/ } \\
\text { kerjasama dengan pihak } \\
\text { lain }\end{array}$ \\
\hline Penguatan Kemitraan & - & 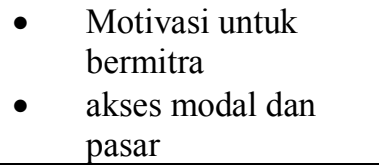 & $\begin{array}{l}\text { Dukungan kebijakan } \\
\text { pemerintah, }\end{array}$ \\
\hline
\end{tabular}

\section{Kesejahteraan}

Kesejahteraan secara umum diartikan sebagai kondisi terpenuhinya segala bentuk kebutuhan hidup, khususnya yang bersifat mendasar seperti makanan, pakaian, perumahan, pendidikan dan perawatan kesehatan. Kesejahteraan dapat dilihat dari berbagai pandangan. Sukirno (1985) dalam Jusfrizal (2004) melihat kesejahteraan sebagai sesuatu yang bersifat subyektif dimana setiap orang mempunyai pedoman, tujuan dan cara hidup yang berbeda-beda sehingga memberikan nilai-nilai yang berbeda pula terhadap faktorfaktor yang menentukan tingkat kesejahteraan mereka. Kesejahteraan adalah suatu tata kehidupan dan penghidupan sosial, material, maupun spiritual yang diliputi rasa keselamatan, kesusilaan dan ketentraman lahir batin yang memungkinkan setiap warga negara untuk mengadakan usaha-usaha pemenuhan kebutuhan jasmani, rohani, dan sosial yang sebaik-baiknya bagi diri, rumah tangga serta masyarakat (Rambe 2001 dalam Sunarti 2006).

Untuk mengukur kesejahteraan masyarakat, BPS menggunakan indikator kondisi sosial ekonomi masyarakat yang diperoleh melalui SUSENAS. Indikator tersebut antara lain kependudukan, pendapatan dan pengeluaran, kesehatan, pendidikan dan perumahan, ketenagakerjaan, serta kondisi sosio ekonomi lainnya (BPS 2013). Indikator yang digunakan BPS (2013) untuk mengukur kesejahteraan rakyat, yaitu (1) kependudukan, (2) tingkat pendapatan dan pengeluaran; (3) kesehatan diukur melalui keluhan sakit, pemanfaatan fasilitas kesehatan, pemberian ASI, angka morbiditas, penolong persalinan; (4) pendidikan: angka partisipasi sekolah dan angka melek huruf; (5) kondisi tempat tinggal meliputi material atap, dinding, lantai yang digunakan dan juga fasilitas yang dimiliki oleh rumah tangga, (6) ketenagakerjaan, dan (7) kondisi sosial lainnya.

\section{Kerangka Pemikiran}

Kerangka penelitian penelitian ini menghubungkan antara variabel pelaksanaan strategi pemberdayaan dengan tingkat kesejahteraan, seperti pada Gambar 1. Dalam penelitian ini strategi pemberdayaan merupakan kegiatan yang dilakukan oleh Kampoeng Ternak untuk mencapai tujuan pemberdayaan yang diinginkan. Aktivitas pemberdayaan tersebut seperti pembentukan kelompok, pelatihan, mengembangkan jejaring peternak dan lain-lain.

Gambar 1 menunjukkan hubungan yang diuji pada penelitian ini, yaitu strategi pemberdayaan dengan tingkat kesejahteraan. Pada penelitian ini, variabel strategi pemberdayaan merupakan aktivitas yang dilaksanakan oleh Kampoeng Ternak untuk memberdayakan peternak. Variabel strategi pemberdayaan dibangun berdasarkan Peraturan Menteri Dalam Negeri No 51 Tahun 
2007 tentang Pembangunan Kawasan Perdesaan Berbasis Masyarakat yang menyebutkan terdapat tiga pola strategi pemberdayaan yaitu peningkatan kapasitas, penguatan kelembagaan dan pengembangan kemitraan serta teori dari Parson et al (1995) dalam Suharto (2005) yang menyebutkan terdapat tiga araz pemberdayaan yaitu araz mikro, mezo dan makro.

Berdasarkan hasil penelitiaan sebelumnya, strategi pemberdayaan melalui peningkatan kapasitas, penguatan kelembagaan/kelompok dan penguatan kemitraan berpengaruh terhadap kesejahteraan peternak. Melalui strategi peningkatan kapasitas, maka akan melahirkan sumber daya manusia yang unggul yang mampu secara mandiri menganalisis permasalahan yang dihadapi serta mampu berfikir alternatif pemecahan masalahnya sendiri. Strategi peningkatan kapasitas dapat dicapai melalui kegiatan pembelajaran melalui pendidikan, pelatihan keterampilan. Strategi pengembangan kapasitas diukur melalui, proses pembelajaran, dan aspek tingkat pengetahuan, keterampilan serta sikap.

Kemudian melalui strategi penguatan kelembagaan dapat menguatkan kelembagaan yang ada sehingga mampu membentuk usaha kolektif kuat. Strategi penguatan kelembagaan dapat diukur melalui peranan kepemimpinan, kelengkapan struktur kelembagaan, partisipasi dalam kelembagaan, proses pendampingan dan motivasi berkelompok. Strategi penguatan kemitraan/ jaringan sosial dilihat dengan akses permodalan, akses pemasaran, dukungan kebijakan pemerintah dan motivasi bermitra. Tingkat kesejahteraan peternak diukur dengan menggunakan indikator BPS 2013 yaitu tingkat pendapatan, tingkat konsumsi dan pengeluaran, kesehatan, tingkat pendidikan dan kondisi tempat tinggal. Selanjutnya, akan diuji hubungan antarra strategi pemberdayaan yang dilakukan dengan tingkat kesejahteraan peternak. Selanjutnya, untuk memudahkan pemehaman, maka hubungan kedua variabel dapat digambarkan pada Gambar 1.

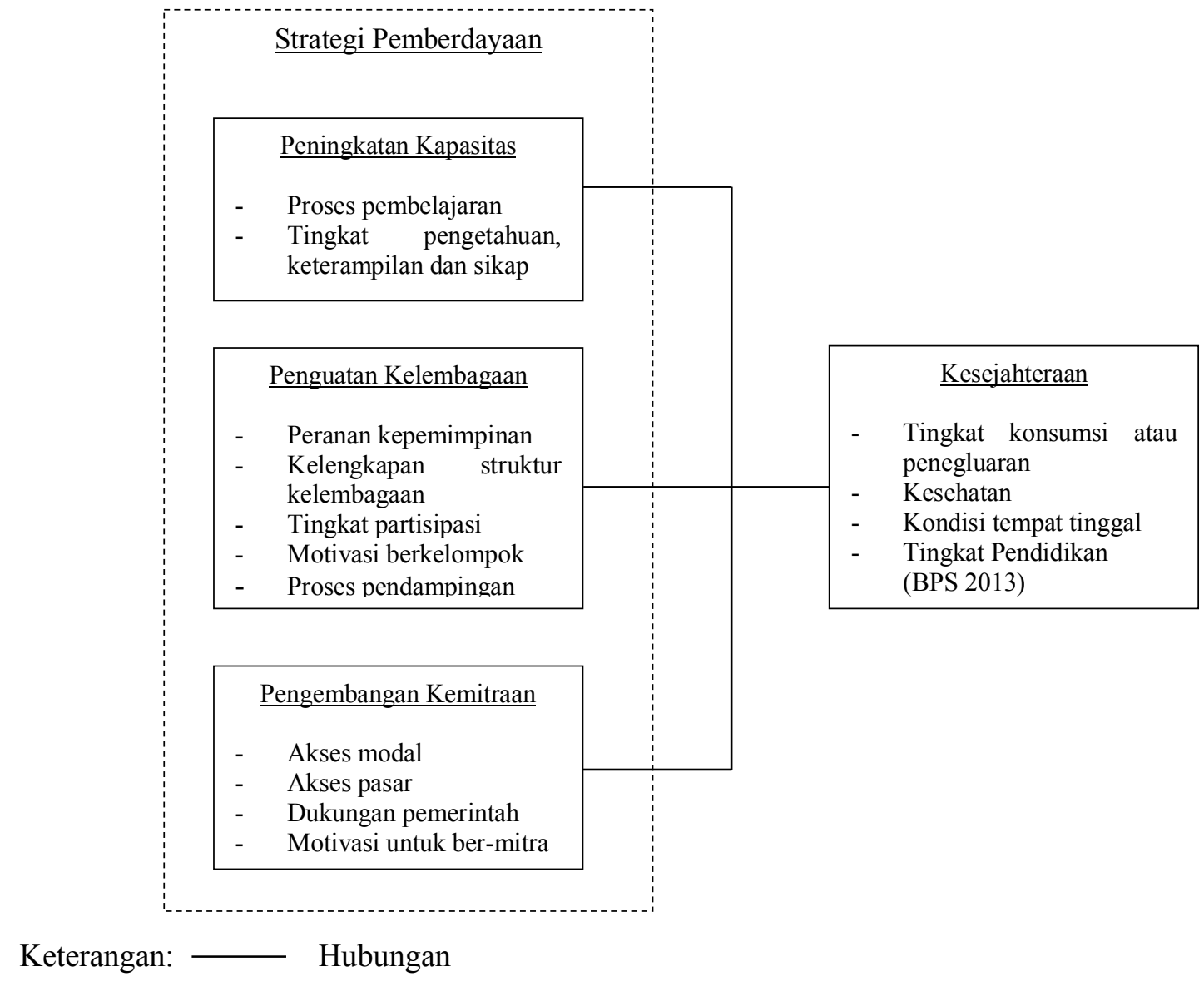

Gambar 1 Kerangka pemikiran 


\section{Hipotesis Penelitian}

Hipotesis uji dalam pebelitian ini yaitu diduga terdapat hubungan antara implementasi strategi pemberdayaan dengan tingkat kesejahteraan. Hipotesis uji tersebut, dibuat ke dalam beberapa pernyataan hipotesis yang mendukung, yaitu sebagai berikut:

1. Terdapat hubungan antara peningkatan kapasitas dengan tingkat kesejahteraan;

2. Terdapat hubungan antara penguatan kelembagaan dengan tingkat kesejahteraan;

3. Terdapat hubungan antara pengembangan kemitraan dengan tingkat kesejahteraan.

\section{METODE PENELITIAN}

Metode penelitian yang digunakan adalah metode kuantitatif dengan pendekatan penelitian survei dan didukung dengan metode kualitatif. Penelitian kuantitatif berorientasi pada survei yang berasal dari data sampel di lapangan. Sampel diambil untuk mewakili keseluruhan populasi. Pendekatan lapang pun dilakukan dengan penggalian informasi dari responden dengan kuesioner dan wawancara. Selain metode penelitian kuantitatif yang telah dijelaskan, penelitian ini didukung pula oleh pendekatan kualitatif. Teknik yang digunakan dalam penelitian ini adalah wawancara tidak terstruktur, wawancara mendalam, observasi dan analisa data sekunder yang menjadi sumber referensi berkaitan dengan topik.

Penelitian dilakukan di wilayah program pemberdayaan Kampoeng Ternak di Kabupaten Sukabumi yaitu kelompok peternak yang tergabung dalam Koperasi Peternak Serba Usaha (KPSU) Riung Mukti yang terdapat di Desa Palasari Girang, Desa Pulosari, Desa Walangsari, dan Desa Tugu Bandung. Penelitian dilakukan selama enam bulan dimulai pada bulan Januari hingga bulan Juni 2015.

Populasi dalam penelitian ini adalah peternak yang mengikuti program pemberdayaan Kampoeng Ternak dan tergabung dalam KPSU Riung Mukti. Unit analisa dalam penelitian ini adalah individu peternak. Responden ditentukan dengan metode pengambilan acak sederhana (simple random sampling) sebanyak 40 responden peternak.
Data yang digunakan pada penelitian ini berupa data primer dan data sekunder. Data primer yaitu data yang didapatkan melalui observasi, kuesioner, dan wawancara kepada responden dan informan di lokasi penelitian. Kuesioner telah diuji coba untuk mengetahui reliabilitas dari kuesioner tersebut. Hasil uji reliabililitas pada kuesioner penelitian ini menunjukkan angka 0.850 artinya kuesioner memiliki reliabilitas tinggi. Adapun data sekunder diperoleh peneliti melalui studi literatur yang berkaitan dengan penelitian ini.

Data pada penelitian ini diolah dengan menggunakan software Statistical Product and Service Solution 17.0 dan Ms. Excell 2010. Analisis data yang digunakan Uji Korelasi Rank Spearman. Uji Korelasi Rank Spearman untuk melihat hubungan antara strategi pemberdayaan dengan tingkat kesejahteraan.

\section{HASIL DAN PEMBAHASAN}

\section{Gambaran Umum Program Pemberdayaan Kampoeng Ternak}

Kampoeng Ternak merupakan organisasi atau jejaring community entrepreneurship di bawah naungan Dompet Dhuafa yang bertujuan untuk memberdayakan petani peternak. Awal mula terbentuknya Kampoeng Ternak Nusantara (KTN) yaitu pada tahun 1994, Dompet Dhuafa (DD) memulai program penyebaran hewanhewan kurban ke wilayah-wilayah miskin di Indonesia. Pada tahun 1997 nama program ini diganti menjadi Tebar Hewan Kurban (THK). Pada tahun 2000 program Tebar Hewan Kurban mulai disinergikan dengan program pemberdayaan peternak yang menyiapkan hewan kurban di daerah-daerah sasaran. Kemudian pada Juni 2005, dibentuk Kampoeng Ternak sebagai jejaring Dompet Dhuafa yang bertugas mengembangkan program peternakan yang berbasis pada peternakan rakyat (peternak mustahik dan tradisional).

Kampoeng Ternak sebagai suatu organisasi atau jejaring, memiliki sasaran yang ingin dicapai dan aturan dalam pelaksanaan setiap program. Kampoeng Ternak memiliki visi yang ingin dicapai yaitu menjadi organisasi terdepan dalam bisnis peternakan berbasis pemberdayaan masyarakat. Visi tersebut dicapai melalui misi yang dimiliki Kampoeng Ternak yaitu: (1) menumbuhkembangkan entitas dan iklim social 
entrepreneurship dalam komunitas peternakan rakyat; (2) meningkatkan kualitas kesejahteraan peternak; (3) membangun jaringan peternakan rakyat yang terbaik di Indonesia; dan (4) menyelenggarakan bisnis peternakan dan turunannya yang profit, tumbuh, sinambung dan berkah.

Program yang dilakukan Kampoeng Ternak Nusantara tidak hanya program pemberdayaan peternak saja, tetapi juga program Research and Development serta Marketing Board. Pada program pemberdayaan peternak, Kampoeng Ternak menggunakan pendekatan kelompok dalam pelaksanaannya dengan membentuk kelompok-kelompok peternak yang terdiri dari 710 orang peternak. Kegiatan yang dilakukan dalam pemberdayaan berupa kegiatan pelatihan, pendampingan kelompok peternak, membangun jejaring peternakan, dan lain-lain.

Program pemberdayaan peternak hingga tahun 2014 sudah mencapai 22 provinsi di Indonesia, diantaranya yaitu Oku Timur, Lampung, Banten, Bogor, Sukabumi, Sumedang, Garut, Tasikmalaya, Karawang, Nusa Tenggara Barat, dan lain-lain. Program ini juga sudah melibatkan 1.475 kepala keluarga petani-peternak dhuafa dan tradisional. Selain mendapatkan pembinaan teknis beternak dan pembangunan etos kerja, semangat untuk mandiri dan pendalaman pemahaman spiritual.

\section{Analisis Strategi Program Pemberdayaan}

Strategi diartikan sebagai suatu cara yang dilakukan untuk mencapai tujuan tertentu. Pada penelitian ini, strategi pemberdayaan didefinisikan sebagai suatu kegiatan yang diupayakan dan dilakukan oleh organisasi atau lembaga dalam hal ini pemberdayaan dilakukan oleh Kampoeng Ternak untuk mencapai tujuantujuan yang diharapkan. Pada pembahasan ini, akan menganalisis strategi pemberdayaan, meliputi peningkatan kapasitas, penguatan kelompok dan pengembangan kemitraan. Penjelasan analisis didasarkan pada data kuantitatif yang didapatkan di lapangan dan disajikan dalam tabel frekuensi dan didukung dengan data kualitatif deskriptif.

\section{Analisis Strategi Pemberdayaan melalui Peningkatan Kapasitas}

Peningkatan kapasitas dalam penelitian ini didefinisikan sebagai suatu bentuk aktivitas yang dilakukan untuk meningkatkan kualitas sumber daya manusia (SDM) yang dapat dilakukan melalui proses pendidikan, pelatihan maupun pembelajaran. Suwardi (2011) menyebutkan strategi pemberdayaan melalui peningkatan kapasitas bertujuan agar masyarakat dapat berpikir dan memecahkan masalahnya sendiri. Melalui peningkatan kapasitas masyarakat mampu diberdayakan dan mampu menciptakan iklim usaha yang kondusif, membangun kesadaran diri untuk memperbaiki nasibnya. Variabel yang digunakan untuk melihat pelaksanaan strategi pemberdayaan melalui peningkatan kapasitas meliputi proses pembelajaran dan perubahan tingkat pengetahuan, keterampilan serta sikap. Hasil survey di lapangan menunjukka bahwa pelaksanaan strategi pemberdayaan melalui peningkatan kapasitas tergolong dalam kategori tinggi (lihat Tabel 2).

Tabel 2 Jumlah dan persentase responden menurut peningkatan kapasitas

\begin{tabular}{lcc}
\hline Kategori & Jumlah $(\mathrm{n})$ & Persentase $(\%)$ \\
\hline Tinggi & 19 & 47.5 \\
Sedang & 17 & 42.5 \\
Rendah & 4 & 10.0 \\
\hline Total & 40 & 100.0 \\
\hline
\end{tabular}

Tabel 2 menunjukkan bahwa jumlah dan persentase responden menurut strategi pemberdayaan peningkatan kapasitas tergolong tinggi yaitu sebanyak 19 responden dengan persentase $47.5 \%$. Sedangkan untuk kategori sedang sejumlah 17 responden dengan persentase $42.5 \%$ dan kategori rendah sebanyak 4 responden dengan persentase $10 \%$.

Strategi pemberdayaan melalui peningkatan kapasitas diukur berdasarkan variabel proses pembelajaran dan tingkat pengetahuan, keterampilan dan sikap. Berdasarkan Tabel 2, dapat diketahui bahwa strategi pemberdayaan melalui peningkatan kapasitas tergolong dalam kategori tinggi. Hal ini berarti strategi ini berhasil meningkatkan kapasitas dan kualitas SDM peternak. Hal ini dipengaruhi oleh proses pembelajaran yang rutin dilakukan dalam pertemuan kelompok. Variabel proses pembelajaran tergolong dalam kategori tinggi dengan jumlah responden sebanyak 17 dan persentase $42.5 \%$. Pada indikator proses 
pembelajaran, kegiatan pembelajaran dilakukan rutin setiap pertemuan kelompok diadakan. Selain itu, selama kegiatan pemberdayaan berlangsung dilakukan kegiatan pendampingan dari Kampoeng Ternak. Pendamping program Pendamping memiliki peranan yang sangat penting dalam proses pemberdayaan peternak, sehingga pendamping harus memiliki kriteria tertentu dan mampu hidup berdampingan dengan peternak. Hal ini sesuai dengan pernyataan yang diungkapkan oleh pendamping program yang juga merupakan manager koperasi peternak Riung Mukti saat ini.

“..ketika peternak tertarik untuk mengikuti
program, peternak tersebut diwajibkan
mengikuti LWK. Pada saat LWK, peternak
diberikan materi pembelajaran terkait teknik
pemeliharaan ternak, keagamaan dan lain-
lain. Selain itu, pada saat sudah terbentuk
kelompok juga dilakukan pertemuan
kelompok sebagai wadah untuk kegiatan
pembelajaran dan berdiskusi antara peternak
dengan pendamping, saat itulah peternak
memperoleh pengetahuan dan keterampilan
guna meningkatkan kapasitas dan
kemampuan mereka.." (Bapak A, manager
koperasi dan pendamping program)

Strategi peningkatan kapasitas terclihat pada aspek pengetahuan, keterampilan dan sikap responden yang berturut-turut tergolong dalam kategori tinggi, tinggi dan sedang. Hal ini mengindikasikan, strategi pemberdayaan ini telah berhasil meningkatkan pengetahuan dan keterampilan yang dimiliki oleh peternak terkait dengan teknik atau cara memelihara ternak dengan baik yang pada akhirnya diharapkan pada produktivitas ternak yang tinggi.

\section{Analisis Strategi Pemberdayaan melalui Penguatan Kelompok}

Penguatan kelembagaan didefinisikan sebagai proses untuk memperbaiki kemampuan lembaga guna mengefektifkan penggunaan sumber daya manusia dengan keuangan yang tersedia (Israel 1990) . Hasil penelitian yang dilakukan Puhazhendhi; Satyasal (2001); Kalkut (2001) dan Das (2001) dalam Suwardi (2011) yang menyimpulkan bahwa pemberdayaan terhadap masyarakat miskin dengan penguatan kapasitas kelompok akan (1) mampu membangun kegiatan kelompok dengan meningkatkan kesejahteraan anggotanya; (2) berhasil menumbuhkembangkan modal sosial anggota seperti sifat tekun berusaha, rasa percaya diri; dan (3) program mampu menumbuhkembangkan kesetaraan gender

Kelembagaan yang dimaksud dalam penelitian ini adalah kelompok peternak yang telah dibentuk dalam program pemberdayaan Kampoeng Ternak. Secara konseptual, penguatan kelompok merupakan proses pembelajaran kelompok secara partisipatif yang bertujuan untuk membentuk kelembagaanya atau kelompoknya sebagai wadah belajar dan kerjasama untuk memperbaiki taraf hidup. Variabel yang digunakan untuk melihat pelaksanaan strategi pemberdayaan melalui penguatan kelompok yaitu peranan pemimpin, kelengkapan struktur kelompok, tingkat partisipasi dalam kelompok, proses pendampingan, dan tingkat motivasi berkelompok. Hasil survei di lapangan menunjukkan strategi pemberdayaan melalui penguatan kelompok tergolong dalam kategori tinggi (lihat Tabel 3).

Tabel 3 Jumlah dan persentase responden menurut penguatan kelompok

\begin{tabular}{lcc}
\hline Kategori & Jumlah $(\mathrm{n})$ & Persentase $(\%)$ \\
\hline Tinggi & 19 & 47.5 \\
Sedang & 18 & 45.0 \\
Rendah & 3 & 7.5 \\
\hline Total & 40 & 100.0 \\
\hline
\end{tabular}

Berdasarkan Tabel 23 dapat diketahui bahwa jumlah dan persentase responden berdasarkan penguatan kelompok tergolong dalam kategori tinggi. Jumlah dan persentase responden yang tergolong dalam kategori tinggi adalah sebanyak 19 responden dengan persentase $47.5 \%$. Sedangkan, jumlah dan persentase responden yang tergolong dalam kategori sedang adalah sebanyak 18 responden dengan persentase $45 \%$ dan sebanyak tiga responden tergolong dalam kategori rendah dengan persentase $7.5 \%$. Berdasarkan hasil analisis tersebut, dapat dikatakan bahwa strategi pemberdayaan melalui penguatan kelompok sudah berjalan dengan baik. Hal ini terbukti dengan keberlangsungan kelompok yang masih tetap bertahan hingga saat ini.

Kelima variabel memberikan pengaruh terhadap hasil analisis data strategi penguatan kelompok sehingga tergolong tinggi. Pada variabel peranan pemimpin, hasil data di lapangan menunjukkan tergolong dalam kategori tinggi dengan jumlah 
responden sebanyak 19 (47.5\%). Pemimpin memiliki peranan dan pengaruh yang besar dalam dinamika kelompok. Peranan ketua kelompok dapat dilihat pada keaktifan dalam kegiatan kelompok, ketegasan dalam menerapkan aturan dan hukuman, keterbukaan, dan sikap perhatian terhadap anggota kelompoknya.

Kemudian pada variabel kelengkapan struktur kelompok tergolong dalam kategori sedang dengan jumlah responden sebanyak 21 (52.5\%). Kelengkapan struktur kelompok merupakan salah satu elemen yang terdapat dalam suatu kelembagaan atau kelompok. Kelengkapan struktur kelompok sangat berkaitan dengan dinamika kelompok dan keberlangsungan kelompok tetap mampu bertahan atau tidak. Kelengkapan struktur kelompok dilihat berdasarkan peran dan fungsi pengurus kelompok serta tingkat keaktifan pengurus dalam kegiatan berkelompok. Peran dan fungsi pengurus dalam kelompok sudah berjalan dengan baik. Hal ini sesuai dengan pernyataan yang diungkapkan oleh ketua kelompok peternak berikut ini.

\section{“..Kalo di dalam kelompok, pengurus itu ada ketua, sekertaris, bendahara dan juru ternak (juter). Sekertaris bertugas untuk mencatat setiap laporan kejadian ternak diantara anggota dan mencatat dalam setiap pertemuan kelompok, bendahara bertugas untuk mengatur dana yang dimiliki kelompok, sementara juter bertugas untuk memeriksa kesehatan hewan diantara peternak anggota kelompok. Pengurus sudah melakukan tugasnya dengan baik, dengan adanya buku pencatatan, catatan absensi, catatan bagi hasil.." (Bapak A, Ketua Kelompok)}

Selanjutnya, pada variabel tingkat partisipasi dalam kelompok, hasil survei di lapangan menunjukkan variabel tersebut tergolong dalam kategori sedang dengan jumlah responden sebanyak $22(55 \%)$. Tingkat partisipasi peternak dalam kegiatan kelompoknya, sangat berpengaruh terhadap keberlangsungan kelompoknya untuk tetap bertahan. Tingkat partisipasi dalam kelompok ditunjukkan dengan kehadiran pada setiap kegiatan atau pertemuan kelompok dan juga frekuensi menyampaikan aspirasi atau pendapatnya ketika pertemuan kelompok. Tingkat kehadiran peternak dalam pertemuan kelompok pada umumnya tinggi, karena terdapat peraturan kelompok yang mengatur kehadiran peternak dalam setiap pertemuan. Sedangkan pada frekuensi menyampaikan pendapat tergolong dalam kategori sedang, karena eberapa responden saat pertemuan dan berdiskusi kelompok hanya hadir saja tetapi tidak semua responden mengeluarkan pendapat dan aspirasinya.

Pada variabel proses pendampingan kelompok, hasil survey di lapangan menunjukkan tergolong dalam kategori tinggi dengan jumlah responden sebanyak $18(45 \%)$. Penelitian yang dilakukan Suwardi (2010) menghasilkan bahwa proses pendampingan kelompok melalui pembelajaran kelompok yang baik akan meningkatkan tingkat kesadaran kelompok, tingkat pembentukan visi kelompok, tingkat pengorganisasian kelompok dan tingkat pelaksanaan desakan kelompok (aturan dan sanksi). Proses pendampingan kelompok diukur berdasarkan pandangan responden terhadap pendamping program dalam upaya melakukan pengorganisasian kelompok, memotivasi kelompok untuk maju, penyelesaian masalah kelompok dan interaksi pendamping dengan peternak.

Selanjutnya, pada variabel tingkat motivasi berkelompok tergolong dalam kategori tinggi dengan jumlah responden sebanyak $24(60 \%)$. Penelitian yang dilakukan sebelumnya oleh Suwardi (2010) menghasilkan bahwa tingkat dinamika kelompok dipengaruhi oleh pendampingan dan motivasi berkelompok. Tingkat motivasi berkelompok diukur berdasarkan tingkat keinginan untuk membentuk kelompok dan manfaat yang diterima dengan berkelompok. Dari sejumlah responden, mengungkapkan bahwa mereka lebih senang berkelompok dibandingkan melakukan usaha ternak secara individu. Hal ini dikarenakan menurut peternak dengan berkelompok akan memudahkan mereka jika menghadapi masalah dalam pemeliharaan ternak, responden dapat berdiskusi dengan peternak lainnya untuk menemukan solusinya.

Kelompok sebagai wadah pembelajaran dan unit usaha bersama bagi anggotanya memiliki peranan penting dalam pelaksanaan program pemberdayaan. Keberadaan kelompok telah memberikan manfaat kepada peternak seperti sebagai media berdiskusi, berusaha bersama dan lain-lain. Manfaat yang sudah dirasakan oleh peternak, akan menyebabkan peternak tersebut 
akan mempertahankan keberadaan kelompoknya. Keberhasilan program pemberdayaan dapat dilihat salah satunya yaitu dengan keberlanjutannya dan kemandirian dari peserta program. Diharapkan dengan keberlangsungan kelompok peternak mampu mensejahterakan anggotanya.

\section{Analisis Strategi Pemberdayaan melalui Pengembangan Kemitraan}

Kemitraan diartikan sebagai konsep kerjasama antara usaha kecil dengan usaha menengah atau usaha besar disertai dengan pembinaan, dengan memperhatikan prinsip saling menguntungkan dan memperkuat. Variabel yang digunakan untuk mengukur strategi pemberdayaan melalui pengembangan kemitraan yaitu akses pemasaran, akses permodalan, tingkat dukungan pemerintah dan tingkat motivasi bermitra. Hasil survei di lapangan menunjukkan strategi pemberdayaan melalui pengembangan kemitraan tergolong dalam kategori sedang (lihat Tabel 4).

Tabel 4 Jumlah dan persentase responden menurut pengembangan kemitraan

\begin{tabular}{lcc}
\hline Kategori & Jumlah $(\mathrm{n})$ & Persentase $(\%)$ \\
\hline Tinggi & 19 & 47.5 \\
Sedang & 21 & 52.5 \\
Rendah & - & - \\
\hline Total & 40 & 100.0 \\
\hline
\end{tabular}

Berdasarkan Tabel 4 dapat diketahui bahwa jumlah dan persentase responden menurut pengembangan kemitraan tergolong dalam kategori sedang. Jumlah dan persentase responden yang tergolong dalam kategori sedang adalah sebanyak 21 responden dengan persentase $52.5 \%$. Sedangkan, jumlah dan persentase responden yang tergolong dalam kategori tinggi adalah sebanyak 19 responden dengan persentase 47.5\%. Berdasarkan analisis tersebut strategi pemberdayaan melalui pengembangan kemitraan tergolong dalam kategori sedang. Variabel yang digunakan untuk mengukur pelaksanaan strategi pengembangan kemitraan yaitu akses modal, akses pasar, tingkat dukungan pemerintah dan tingkat motivasi bermitra.

Hasil survei di lapangan menunjukkan bahwa variabel akses modal tergolong dalam kategori sedang $(70 \%)$ sedangkan variabel akses pemasaran tergolong dalam kategori tinggi
(100\%). Sejumlah responden mengatakan bahwa dalam akses memperoleh modal tidaklah sulit dan cukup banyak tersedia sumber modal. Namun, responden mengatakan masih belum membutuhkan pinjaman modal dari desa atau bank, responden lebih memilih untuk meminjam modal kepada tengkulak atau koperasi. Kemudian, dalam hal akses pemasaran ternak, responden tidak mengalami kesulitan dalam menjual ternaknya. Umumnya, responden menjual ternaknya pada tengkulak atau orangorang yang membutuhkan untuk keperluan tertentu. Selain itu, terkadang responden juga menjual ternaknya pada koperasi atau Kampoeng Ternak.

Selanjutnya, pada variabel tingkat dukungan pemerintah dan tingkat motivasi bermitra tergolong dalam kategori sedang. Jumlah dan persentase responden menurut tingkat dukungan pemerintah sebanyak 35 dengan persentase $87.5 \%$. Hal ini disebabkan sejumlah responden mengungkapkan bahwa pemerintah belum pernah memberikan bantuan dalam bentuk apapun untuk mengembangkan usaha peternakannya. Sedangkan beberapa responden mengungkapkan, pernah mendapatkan bantuan dari pemerintah seperti bansos, P2WKSS berupa bantuan pemberian ternak. Kemudian, jumlah dan persentase responden menurut tingkat motivasi bermitra sebanyak 24 dengan persentase $60 \%$.

Strategi pemberdayaan melalui pengembangan kemitraan dilakukan oleh Kampoeng Ternak dengan cara memberikan motivasi kepada peternak untuk berusaha dan memiliki etos kerja tinggi serta diwujudkan dalam lembaga Koperasi Riung Mukti yang mengelola keenam kelompok peternak dan berusaha memajukan peternak dengan membentuk kemitraan dengan berbagai pihak. Pengembangan kemitraan dilakukan agar peternak mampu meningkatkan usaha dan kesejahteraannya. Diharapkan dengan koperasi melakukan kemitraan dengan berbagai pihak, manfaatnya dapat dirasakan oleh anggota. Hal tersebut seperti yang diungkapkan oleh manager Koperasi Riung Mukti berikut ini.
“...Peternak tidak hanya diberikan materi terkait teknik pemeliharaan ternak saja, tetapi juga diberikan motivasi untuk melakukan usaha dan memiliki etos kerja tinggi untuk maju. Baik peternak atau kelompok dapat melakukan kemitraan selain dengan Kampoeng Ternak, tetapi tetap harus 
melaporkan terlebih dahulu pada koperasi. Koperasi juga melakukan kemitraan dengan berbagai pihak untuk memajukan koperasi dan mensejahterakan anggotanya, sampai saat ini koperasi sudah melakukan kemitraan dengan Chevron, Kampung 99, PT RECCI, Dinas Koperasi dan Perdagangan, dan lainlain...." (Bapak A, Manager Koperasi)

Analisis masing-masing pola pelaksanaan strategi pemberdayaan menunjukkan pada pola pelaksanaan strategi pemberdayaan melalui peningkatan kapsitas termasuk dalam kategori tinggi, pada penguatan kelembagaan termasuk dalam kategori tinggi dan pengembangan kemitraan tergolong dalam kategori sedang. Berdasarkan hasil analisis terebut, pelaksanaan strategi pemberdayaan yang dilakukan termasuk dalam kategori tinggi (lihat Tabel 5).

Tabel 5 Jumlah dan persentase responden menurut pelaksanaan strategi pemberdayaan

\begin{tabular}{lcc}
\hline \multicolumn{1}{c}{ Kategori } & Jumlah $(\mathrm{n})$ & Persentase (\%) \\
\hline Tinggi & 17 & 42.5 \\
Sedang & 13 & 32.5 \\
Rendah & 10 & 25.0 \\
\hline Total & 40 & 100.0 \\
\hline
\end{tabular}

Tabel 5 menunjukkan bahwa pelaksanaan strategi pemberdayaan tergolong tinggi. Jumlah dan persentase responden yang tergolong tinggi adalah 17 responden $(42.5 \%)$, jumlah dan persentase responden tergolong sedang adalah 13 responden $(32.5 \%)$ dan tergolong rendah sebanyak 10 responden dengan persentase $25 \%$. Hasil analisis menunjukkan bahwa pelaksanaan strategi pemberdayaan sudah berjalan dengan baik. Terdapat berbagai faktor yang memepengaruhi pelaksanaan strategi pemberdayaan sehingga dapat berjalan dengan baik. Salah satu faktor yaitu pada pelaksanaan strategi pemberdayaan yang dilakukan oleh Kampoeng Ternak menggunakan pendekatan kelompok. Aktivitas pemberdayaan dilakukan dengan membentuk kelompok-kelompok peternak sebagai wadah untuk mengembangkan diri, berdiskusi dan memajukan usaha bersama.

\section{Analisis Tingkat Kesejahteraan Peternak}

Kesejahteraan didefinisikan sebagai kondisi terpenuhinya segala bentuk kebutuhan hidup. khususnya yang bersifat mendasar seperti makanan, pakaian, perumahan, pendidikan dan perawatan kesehatan. Sementara, menurut Undang-Undang No 11 Tahun 2009 tentang Kesejahteraan Sosial mendefinisikan kesejahteran sebagai kondisi terpenuhinya kebutuhan material, spiritual dan sosial warga negara agar dapat hidup layak dan mampu mengembangkan diri sehingga dapat melaksanakan fungsi sosialnya. Terdapat berbagai indikator yang diungkapkan oleh para ahli dan lembaga tertentu. Badan Pusat Statistik (2014) menggunakan indikator kependudukan, kesehatan dan gizi, pendidikan, ketenagakerjaan, taraf dan pola konsumsi, perumahan dan lingkungan, kemiskinan dan sosial lainnya untuk mengukur kesejahteraan. Indikator yang digunakan untuk menganalisis kesejahteraan peternak yaitu tingkat konsumsi atau pengeluaran, tingkat kesehatan, tingkat pendidikan, dan kondisi tempat tinggal. Hasil survei di lapangan menunjukkan bahwa tingkat kesejahteraan peternak tergolong dalam kategori sedang (lihat Tabel 6).

Tabel 6 Jumlah dan persentase responden menurut tingkat kesejahteraan

\begin{tabular}{lcc}
\hline Kategori & Jumlah (n) & Persentase (\%) \\
\hline Tinggi & 15 & 37.5 \\
Sedang & 18 & 45.0 \\
Rendah & 7 & 17.5 \\
\hline Total & 40 & 100.0 \\
\hline
\end{tabular}

Berdasarkan Tabel 6 dapat diketahui bahwa tingkat kesejahteraan rumah tangga peternak tergolong sedang. Jumlah dan persentase rumah tangga peternak yang tergolong dalam kategori sedang adalah 18 rumah tangga dengan persentase $45 \%$. Sedangkan jumlah dan persentase rumah tangga yang tergolong dalam kategori tinggi adalah sebanyak 15 rumah tangga dengan persentase $37.5 \%$ dan sebanyak tujuh rumah tangga tergolong dalam kategori rendah dengan persentase $17.5 \%$. Hal ini disebabkan pada variabel tingkat pengeluaran dan tingkat pendidikan rumah tangga peternak tergolong sedang. Jumlah dan persentase responden menurut tingkat pengeluaran sebanyak 29 dengan persentase $72.5 \%$. Tingkat pengeluaran dapat menjadi indikator untuk mengukur tingkat pendapatan rumah tangga peternak. Tingkat pengeluaran peternak pada konsumsi pangan 
lebih besar dibandingkan konsumsi non pangan mengindikasikan bahwa tingkat pendapatan rumah tangga peternak tergolong rendah. Karena, semakin tinggi pendapatan rumah tangga maka akan semakin tinggi pula pengeluaran untuk kebutuhan non pangan. Hal ini dikarenakan elastisitas permintaan terhadap makanan umumnya rendah, sedangkan elastisitas permintaan terhadap non makanan tergolong tinggi (BPS 2014).

Sementara pada variabel tingkat kesehatan dan kondisi tempat tinggal tergolong tinggi. Jumlah dan persentase responden menurut kondisi tempat tinggal sejumlah 20 dengan persentase $50 \%$. Kondisi tempat tinggal diukur berdasarkan indikator kepemilikan fasilitas rumah tangga, luas lantai rumah, dan material yang digunakan. Selanjutnya, pada variabel tingkat kesehatan jumlah dan persentase reponden sebanyak 32 dengan persentase $80 \%$. Tingkat kesehatan diukur berdasarkan tingkat keluhan dan pemanfaatan fasilitas kesehatan. Hasil data di lapangan menunjukkan, tingkat keluhan sakit yang dirasakan responden sebanyak 10\% responden sering mengalami keluhan sakit dan mengganggu tingkat produktivitas peternak dalam bekerja. Sementara, $90 \%$ responden mengungkapkan tingkat keluhan sakit tergolong dalam kategori jarang dan tidak mengganggu produktivitas kerja peternak. Keluhan yang sering dialami yaitu demam, batuk, flu, dan sakit kepala. Pada indikator pemanfaatan fasilitas kesehatan sebanyak $92.5 \%$ responden mengungkapkan, fasilitas kesehatan yang biasa digunakan ketika sakit yaitu dengan berobat pada mantri atau petugas kesehatan dan puskesmas serta obat warung. Sementara $7.5 \%$ responden menggunakan obat warung ketika sakit. Hal ini berpengaruh terhadap tingkat kesejahteraan rumah tangga peternak yang tergolong sedang.

\section{Analisis Hubungan Strategi Pemberdayaan dengan Kesejahteraan Peternak}

\section{Analisis Hubungan Pola Strategi Pemberdayaan dengan Kesejahteraan Peternak}

Sebuah program pemberdayaan pasti memiliki arah dan strategi untuk mencapai tujuan dari pemberdayaan. Strategi diartikan sebagai suatu cara untuk mencapai tujuan tertentu. Dengan demikian, strategi pemberdayaan diartikan sebagai cara untuk mencapai tujuan dari sebuah proses pelaksanaan pemberdayaan masyarakat. Pemberdayaan masyarakat diartikan sebagai upaya untuk meningkatkan harkat dan martabat lapisan masyarakat yang dalam kondisi sekarang tidak mampu melepaskan diri dari perangkap kemiskinan dan keterbelakangan (Kartasasmita 1996). Pemberdayaan harus didasarkan pada proses pemandirian masyarakat dan tidak menimbulkan ketergantungan pada masyarakat.

Peraturan Menteri Dalam Negeri Nomor 51 Tahun 2007 tentang Pembangunan Kawasan Perdesaan Berbasis Masyarakat menyebutkan pola-pola strategi pemberdayaan yang dapat dilakukan dalam aktivitas pemberdayaan masyarakat yaitu peningkatan kapasitas, penguatan kelompok dan pengembangan kemitraan. Strategi pemberdayaan yang diterapkan dalam aktivitas pemberdayaan mempengaruhi proses sebuah pemberdayaan dalam mencapai tujuannya yaitu kemandirian dan kesejahteraan peternak. Dilakukan uji statistic untuk melihat hubungan masing-masing pola strategi pemberdayaan dengan kesejahteraan (lihat Tabel 7).

Tabel 7 Uji korelasi Rank Spearman pola strategi pemberdayaan dengan tingkat kesejahteraan

\begin{tabular}{|c|c|c|c|}
\hline \multirow[b]{2}{*}{$\begin{array}{l}\text { Pola Strategi } \\
\text { Pemberdayaan }\end{array}$} & \multicolumn{2}{|c|}{$\begin{array}{l}\text { Tingkat } \\
\text { Kesejahteraan }\end{array}$} & \multirow[b]{2}{*}{ Keterangan } \\
\hline & $\begin{array}{l}\text { Koefisien } \\
\text { Korelasi }\end{array}$ & $\begin{array}{l}\text { Nilai } \\
\text { Sig. } \\
(2- \\
\text { tailed) }\end{array}$ & \\
\hline $\begin{array}{l}\text { Peningkatan } \\
\text { Kapasitas }\end{array}$ & 0.227 & 0.158 & $\begin{array}{l}\text { Tidak } \\
\text { Berhubungan }\end{array}$ \\
\hline $\begin{array}{l}\text { Penguatan } \\
\text { Kelompok }\end{array}$ & 0.342 & $0.031^{*}$ & Berhubungan \\
\hline $\begin{array}{l}\text { Pengembangan } \\
\text { Kemitraan }\end{array}$ & 0.310 & 0.051 & $\begin{array}{l}\text { Tidak } \\
\text { berhubungan }\end{array}$ \\
\hline
\end{tabular}

Hasil analisis data di lapangan menunjukkan bahwa pelaksanaan strategi pemberdayaan melalui peningkatan kapasitas peternak tergolong dalam kategori tinggi. Namun demikian, hasil uji korelasi antara pola peningkatan kapasitas dengan tingkat kesejahteraan menunjukkan tidak terdapat hubungan diantara kedua variabel tersebut. Hal tersebut mengindikasikan terdapat beberapa faktor yang menjadi penyebab tidak terdapat hubungan antara kedua variabel tersebut. Hal ini berarti strategi pemberdayaan melalui 
peningkatan kapasitas tidak dapat dilakukan secara sendiri, namun harus dilakukan bersamaan dengan upaya lain seperti pemberian motivasi berusaha, melakukan usaha kolektif, pemberian kesempatan untuk mengembangkan usahanya dan lain-lain. Kartasasmita (1996) mengungkapkan bahwa pada pelaksanaan pemberdayaan selain harus memperkuat potensi atau daya masyarakat, harus dilakukan pula langkah nyata seperti pembukaan akses kepada berbagai peluang yang akan membuat masyarakat semakin berdaya. Hal tersebut seperti yang diungkapkan oleh Ketua Koperasi berikut ini:

“...memang kalau pengetahuan dan
keterampilan peternak sudah terbilang cukup
baik, tapi untuk mencapai kesejahteraan
yang lebih baik lagi kan bukan hanya
kualitas sumberdaya yang baik saja, tetapi
perlu dilakukan upaya lain. Misalkan, cita-
cita dari koperasi ingin membuat pasar
ternak agar dapat melakukan penjualan
ternak secara kolektif, sehingga peternak
dapat menentukan harga pasar...” (Bapak H,
Ketua Koperasi)

Hasil uji korelasi Rank Spearman antara variabel penguatan kelompok dengan tingkat kesejahteraan menunjukkan angka koefisien relasi 0.342 . Hal ini menunjukkan bahwa kedua variabel memiliki hubungan moderat. Nilai signifikan menunjukkan $0.031^{*}$ yang berarti lebih kecil dari $0.05(\mathrm{p}<0.05)$. Hal ini berarti H1 diterima dan H0 ditolak. Berdasarkan hal tersebut, H1 diterima yaitu terdapat hubungan antara penguatan kelompok dengan tingkat kesejahteraan peternak. Indikator yang digunakan untuk mengukur variabel penguatan kelompok adalah peranan pemimpin (ketua kelompok), kelengkapan struktur kelompok, tingkat partisipasi kelompok, proses pendampingan dan tingkat motivasi berkelompok.

Pelaksanaan strategi pemberdayaan melalui penguatan kelompok tergolong dalam kategori tinggi. Kelompok sebagai wadah pembelajaran bagi peternak memberikan berbagai manfaat yang dirasakan oleh anggota kelompok. Struktur kelompok yang lengkap dengan adanya pengurus seperti ketua kelompok, sekertaris, bendahara dan juru ternak (juter) membuat dinamika kelompok berjalan dengan baik. Tingkat motivasi berkelompok yang dimiliki peternak tergolong tinggi dengan begitu peternak akan tetap mempertahankan keberlangsungan kelompoknya.
Kelompok sebagai wadah belajar bersama, berdiskusi terkait hal-hal yang berhubungan dengan pemeliharaan ternak, misalkan jika terdapat ternak yang sakit, peternak dapat berdiskusi di dalam kelompok baik dengan pendamping atau dengan peternak lainnya untuk menemukan solusi terkait kesehatan ternak. Hal tersebut akan mempengaruhi produktivitas ternak yang dipelihara oleh peternak. Pada proses pendampingan kelompok, kelompok diberikan materi dalam bagaimana mengorganisasikan kelompok dan motivasi berusaha. Dengan demikian, keberlangsungan kelompok akan tetap dipertahankan dan kelompok mampu mengorganisasikan diri untuk bergerak maju agar mampu mensejahterahkan anggotanya.

Berdasarkan Tabel 7 dapat diketahui bahwa uji korelasi Rank Spearman antara variabel pengembangan kemitraan dengan tingkat kesejahteraan menunjukkan nilai korelasi koefisien sebesar 0.310 dan nilai signifikan sebesar $0.051(p>0.05)$. Berdasarkan aturan untuk menginterpretasikan hubungan kedua variabel, maka dapat disimpulkan bahwa kedua variabel tidak memiliki hubungan. Dengan demikian, $\mathrm{H} 1$ ditolak dan $\mathrm{H} 0$ diterima. Indikator yang digunakan untuk melihat variabel pelaksanaan pengembangan kemitraan adalah akses modal, akses pemasaran, tingkat dukungan pemerintah dan tingkat motivasi bermitra.

Meskipun tingkat motivasi bermitra peternak tergolong tinggi, namun pelaksanaan strategi pemberdayaan melalui pengembangan kemitraan masih tergolong sedang. Kemitraan yang dilakukan oleh peternak masih belum memberikan manfaat terhadap peternak seperti dalam hal untuk akses modal dan akses pemasaran. Walaupun koperasi sudah melakukan kemitraan dengan berbagai pihak, namun manfaatnya belum menyentuh langsung kepada anggota koperasi yaitu kelompok-kelompok peternak. Hal tersebut dikarenakan, proses untuk memberikan manfaat memerlukan waktu dan koperasi baru berjalan sekitar empat tahun.

\section{Analisis Pemberdayaan dengan Kesejahteraan Peternak}

Kartasasmita (1997) dalam Mardikanto (2010) mengungkapkan bahwa pendekatan utama dalam konsep pemberdayaan adalah bahwa masyarakat bukan sebagai objek dari pembangunan, 
melainkan masyarakat harus dianggap sebagai subyek dari pembangunan. Sehingga pendekatan/ startegi yang harus digunakan dalam pelaksanaan pemberdayaan adalah (1) upaya pemberdayaan harus terarah (targeted); (2) partisipasi aktif masyarakat dan (3) menggunakan pendekatan kelompok. Strategi didefinisikan sebagai cara untuk mencapai suatu tujuan. Dengan demikian, strategi pemberdayaan merupakan cara untuk mencapai tujuan dari sebuah proses pemberdayaan. Tujuan dari pemberdayaan adalah untuk membebaskan masyarakat marginal/ miskin untuk terbebas dari jeratan kemiskinan dan mampu merubah nasibnya secara mandiri. Berdasarkan hasil uji korelasi Rank Spearman, dihasilkan bahwa terdapat hubungan antara pelaksanaan strategi pemberdayaan dengan tingkat kesejahteraan peternak (lihat Tabel 8).

Tabel 8 Uji korelasi Rank Spearman antara strategi pemberdayaan dengan tingkat kesejahteraan

\begin{tabular}{lccc}
\hline & \multicolumn{2}{c}{ Tingkat } & \\
& \multicolumn{2}{c}{ Kesejahteraan } & Keterangan \\
& $\begin{array}{c}\text { Koefisien } \\
\text { Korelasi }\end{array}$ & $\begin{array}{c}\text { Nilai } \\
\text { Sig. (2- } \\
\text { tailed) }\end{array}$ & \\
\hline $\begin{array}{l}\text { Strategi } \\
\text { Pemberdayaan }\end{array}$ & $0.357^{*}$ & O.024 & Berhubungan \\
\hline
\end{tabular}

Hasil uji korelasi Rank Spearman menunjukkan angka koefisien korelasi antara strategi pemberdayaan dengan tingkat kesejahteraan adalah 0.357*. Hasil tersebut menunjukkan bahwa kedua variabel tersebut memiliki hubungan moderat. Berdasarkan nilai probabilitas menunjukkan nilai sebesar $0.024(\mathrm{p}<0.05)$. Nilai tersebut menunjukkan bahwa $\mathrm{H} 1$ diterima yaitu terdapat hubungan nyata antara strategi pemberdayaan dengan tingkat kesejahteraan. Untuk lebih rincinya dapat dilihat pada Tabel 9.

Berdasarkan Tabel 9, dapat diketahui bahwa antara variabel strategi pemberdayaan dengan tingkat kesejahteraan peternak memiliki hubungan positif. Artinya, semakin tinggi strategi pemberdayaan maka akan semakin tinggi pula tingkat kesejahteraan peternak. Hal ini dapat dilihat pada persentase responden yang menurut variabel pelaksanaan strategi pemberdayaan tergolong sedang pada umumnya tingkat kesejahterannya juga tergolong dalam kategori sedang dan tinggi. Jumlah dan persentase responden yang menurut variabel strategi pemberdayaan dan tingkat kesejahteraan tergolong sedang adalah sebanyak 12 responden dengan persentase $30 \%$. Sedangkan jumlah dan persentase responden yang menurut strategi pemberdayaan tergolong sedang dan tingkat kesejahteraan dalam kategori tinggi adalah sebanyak lima responden dengan persentase $12.5 \%$.

Tabel 9 Jumlah dan persentase responden berdasarkan hasil tabulasi silang antara strategi pemberdayaan dengan tingkat kesejahteraan

\begin{tabular}{lcccccccc}
\hline \multirow{2}{*}{ Strategi Pemberdayaan } & \multicolumn{9}{c}{ Tingkat Kesejahteraan } & \multicolumn{2}{c}{ Total } \\
\cline { 2 - 8 } & \multicolumn{2}{c}{ Rendah } & \multicolumn{2}{c}{ Sedang } & \multicolumn{2}{c}{ Tinggi } & \multicolumn{2}{c}{} \\
\cline { 2 - 8 } & $\mathrm{n}$ & $\%$ & $\mathrm{n}$ & $\%$ & $\mathrm{n}$ & $\%$ & $\mathrm{n}$ & $\%$ \\
\hline Rendah & 2 & 5.0 & 2 & 5.0 & 1 & 2.5 & 5 & 12.5 \\
Sedang & 4 & 10.0 & 12 & 30.0 & 5 & 12.5 & 21 & 52.5 \\
Tinggi & 1 & 2.5 & 5 & 12.5 & 8 & 20.0 & 14 & 35.0 \\
\hline Total & 7 & 17.5 & 19 & 47.5 & 14 & 35.0 & 40 & 100.0 \\
\hline
\end{tabular}

Selain itu, Tabel 9 menunjukkan, hubungan antara kedua variabel tergolong dalam hubungan yang searah atau positif, semakin tinggi (baik) pelaksanaan strategi pemberdayaan maka akan semakin tinggi pula tingkat kesejahteraan peternak. Pelaksanaan strategi pemberdayaan dilihat berdasarkan pada variabel peningkatan kapasitas, penguatan kelompok dan pengembangan kemitraan. Berdasarkan analisis sebelumnya, pada variabel peningkatan kapasitas tergolong dalam kategori tinggi, penguatan kelompok tergolong dalam kategori tinggi dan pengembangan kemitraan tergolong dalam kategori sedang. Semakin tinggi (efektif) strategi pemberdayaan yang diimplementasikan akan mempengaruhi pelaksanaan program 
pemberdayaan dalam mencapai tujuannya salah satunya yaitu meningkatkan kesejahteraan peternak.

Strategi pemberdayaan tidak dapat dilepaskan dari sebuah proses pemberdayaan. Ketiga pola strategi pemberdayaan tersebut tidak dapat dipisahkan satu sama lain. Strategi peningkatan kapasitas merupakan strategi untuk meningkatkan kualitas SDM peternak dengan memberikan pengetahuan dan keterampilan terkait teknik pemeliharaan ternak agar produktivitas ternak meningkat. Namun, peningkatan kapasitas harus menggunakan pendekatan kelompok. Keberadaan kelompok sebagai wadah bagi anggotanya untuk belajar bersama, berdiskusi, akan memberikan manfaat bagi anggotanya. Pembelajaran melalui pendekatan kelompok akan mempengaruhi dinamika kelompok dan membentuk kelompok yang aktif, partisipatif dan bermanfaat bagi anggotanya dalam mencapai tujuannya. Selain melalui pembelajaran kelompok, penguatan kelompok dilihat berdasarkan peranan pemimpin dan kelengkapan struktur kelompok. Peranan pemimpin (ketua kelompok) dan pengurus kelompok serta partisipasi anggota kelompok dalam kegiatan kelompok akan mempengaruhi dinamika kelompok untuk tetap bertahan dan mencapai tujuan kelompok. Keberlangsungan kelompok untuk tetap bertahan diharapkan dapat menjadi organisasi yang mandiri untuk maju mencapai tujuan yaitu mensejahterakan anggotanya.

\section{SIMPULAN DAN SARAN}

\section{Simpulan}

Program pemberdayaan Kampoeng Ternak melakukan ketiga strategi pemberdayaan yaitu peningkatan kapasitas, penguatan kelembagaan dan pengembangan kemitraan. Indikator yang digunakan untuk melihat peningkatan kapasitas yaitu proses pembelajaran dan perubahan tingkat pengetahuan, keterampilan dan sikap peternak. Berdasarkan analisis indikator tersebut, strategi peningkatan kapasitas tergolong dalam kategori tinggi. Hal ini dapat dilihat pada tingkat pengetahuan dan keterampilan yang dimiliki peternak terkait dengan pemeliharaan ternak tergolong tinggi, serta proses pembelajaran yang selalu dilaksanakan bersamaan dengan pertemuan kelompok.
Strategi pemberdayaanm melalui penguatan kelompok diukur dengan menggunakan indikator peranan pemimpin, kelengkapan struktur kelompok, tingkat partisipasi dalam kelompok, proses pendampingan dan tingkat motivasi berkelompok. Berdasarkan indikator tersebut, penguatan kelompok tergolong dalam kategori tinggi. Keberadaan kelompok sudah memberikan manfaat positif kepada anggota kelompok peternak. Kelompok sebagai wadah belajar bagi anggota peternak, tempat diskusi bersama, dan berusaha maju bersama-sama. Strategi pengembangan kemitraan diukur menggunakan idnikator tingkat akses permodalan, akses pemasaran, tingkat dukungan pemerintah dan tingkat motivasi bermitra. Hasil data di lapangan menunjukkan, strategi pengembangan kemitraan tergolong dalam kategori sedang. Hal ini dikarenakan peternak belum merasakan manfaat yang sepenuhnya dari kemitraan, dan dukungan pemerintah pun tegrolong sedang. Sejumlah responden mengungkapkan pemerintah belum pernah memberikan bantuan dalam pengembangan usaha ternaknya.

Berdasarkan hasil analisis data di lapangan, tingkat kesejahteraan rumah tangga peternak tergolong dalam kategori sedang. Tingkat kesejahteraan diukur dengan menggunakan indikator BPS dalam SUSENAS 2013 yang telah dimodifikasi dalam penelitian ini. Indikator yang digunakan yaitu tingkat pengeluaran, tingkat kesehatan, tingkat pendidikan dan kondisi tempat tinggal. Hasil analisis data menunjukkan indikator pengeluaran termasuk dalam kategori sedang, tingkat kesehatan tergolong dalam kategori tinggi, tingkat pendidikan tergolong dalam kategori sedang dan kondisi tempat tinggal tergolong dalam kategori tinggi.

Berdasarkan hasil uji korelasi Rank Spearman, terdapat hubungan yang moderat antara variabel strategi pemberdayaan dengan tingkat kesejahteraan rumah tangga peternak. Hasil uji korelasi pada masing-masing pola strategi pemberdayaan, menunjukkan hanya pada variabel strategi pemberdayaan melalui penguatan kelompok yang memiliki hubungan dengan tingkat kesejahteraan rumah tangga peternak dan hubungan tersebut tergolong moderat. Sedangkan, pada dua strategi lainnya tidak terdapat hubungan dengan tingkat kesejahteraan. Hal tersebut menunjukkan, strategi pemberdayaan melalui penguatan kelompok 
dinilai tepat dalam pelaksanaanya. Pemberdayaan melalui pendekatan kelompok dapat mempengaruhi dinamika kelompok untuk terus berusaha berkembang untuk memajukan anggotanya. Kelompok sebagai wahana belajar bagi anggota kelompok telah memberikan manfaat positif bagi anggotanya.

\section{Saran}

Pemberdayaan bertujuan untuk memandirikan dan memampukan masyarakat agar mampu merubah nasibnya untuk terbebas dari jeratan kemiskinan. Sehingga, untuk mencapai tujuan tersebut perlu dirumuskan strategi pemberdayaan yang tepat. Hendaknya dalam pelaksanaan pemberdayaan, perlu dilihat potensi yang dimiliki oleh masyarakat. Masyarakat dianggap sebagai subyek dari program bukan sebagai objek. Selama ini, umumnya program-program pemberdayaan baik dari pemerintah maupun swasta seringkali tidak berjalan atau tidak ada keberlanjutannya. Hal tersebut dikarenakan masyarakat tidak terlibat dalam setiap tahapan prosesnya. Hal paling substansial dalam strategi pemberdayaan adalah bagaimana pemberdayaan terebut mampu memberikan manfaat bagi masyarakat sehingga apabila masyarakat sudah merasakan manfaatnya, keberlanjutan program akan tetap dipertahankan.

Hal lain yaitu dalam proses pemberdayaan tidak memungkiri keterlibatan dari setiap pihak baik dari pemerintah, swasta maupun masyarakat. Pada umunya, pemberdayaan baik yang dilakukan oleh pemerintah atau swasta dilakukan masing-masing dengan tidak melibatkan pihak lain di dalamnya dan masyarakatpun hanya dianggap sebagai objek penerima program. Tanpa adanya dukungan dari masing-masing pihak, pemberdayaan tidak akan berhasil atau program pemberdayaan tidak berlanjut sebagaimana mestinya. Karena itu diperlukan sinergitas dukungan dari setiap pihak agar program pemberdayaan berjalan dengan baik, selain itu pada pelaksanaan pemberdayaan juga diperlukan pendampingan yang intensif dan berusaha untuk menciptakan keberlanjutan program dan kemandirian masyarakat. Selain itu, upaya pemberdayaan harus dilakukan melalui pendekatan kelompok dan penguatan kelembagaan/ kelompok tersebut menjadi prasayarat keberhasilan program.

\section{DAFTAR PUSTAKA}

[BPS] Badan Pusat Statistik. 2014. Jumlah Penduduk Miskin, Persentase Penduduk Miskin dan Garis Kemiskinan, 1997-2013.

[BPS] Badan Pusat Statistik. 2014. Indikator Kesejahteraan Rakyat.

Israel A. 1990. Pengembangan Kelembagaan: Pengalaman Proyek-Proyek Bank Dunia. Jakarta (ID): Lembaga Penelitian, Pendidikan dan Penerangan Ekonomi dan Sosial [LP3ES].

Jusfrizal. 2004. Pengembangan Program Pembangunan Masyarakat dalam Rangka Peningkatan Kesejahteraan Petani di Kabupaten Siak Propinsi Riau. [Tesis]. Sekolah Pasca Sarjana, Institut Pertanian Bogor. [Internet]. [Diunduh 20 Mei 2015]. Dapat diunduh di http://www.repository.ipb.ac.id

Kartasasmita G. 1996. Pembangunan untuk Rakyat, Memadukan Pertumbuhan dan Pemerataan. Jakarta (ID): PT Pustaka Cidesindo.

Mardikanto T. 2010. Konsep-konsep Pemberdayaan Masyarakat.. Solo (ID): Fakultas Pertanian, UNS.

[Permendagri]. Peraturan Menteri Dalam Negeri No 51 Tahun 2007. 2007. Peraturan tentang Pembangunan Kawasan Pedesaan Berbasis Masyarakat. [Internet]. [Diunduh 1 November 2014]. Dapat diunduh di http://pmd.kemendagri.go.id/produkhukum/category/permendagri

Suharto E. 2005. Membangun Masyarakat Memberdayakan Rakyat: Kajian strategis Pembangunan Kesejahteraan Sosial dan Pekerjaan Sosial. Bandung (ID): Refika Aditama.

Sunarti E. 2006. Indikator Keluarga Sejahtera: Sejarah Pengembangan, Evaluasi Selatan: Studi Pilkada di Sulawesi Selatan Th 2007-2008. [internet]. [diunduh 16 Maret 2014]. Diunduh dari: http://repository.ipb.ac.id/handle/123456789/54504

Suwardi S. 2010. Pengaruh Pembelajaran Program Penguatan Kapasitas Kelompok terhadap Dinamika Kelompok. Ilmu-ilmu Pertanian. [Internet]. [Diunduh 28 November 2014]. $\begin{array}{lllll} & \text { Vol } & 6 & \text { (1). Hlm 10-21. }\end{array}$ http://stppyogyakarta.ac.id/wpcontent/upload s/2012/04/IIP06012010SurachmanSuwardi.p df 
2011. Implikasi Pelatihan Penguatan Kapasitas Kelompok dalam Mengembangkan Kemandirian Usaha. [Jurnal]. Ilmu- ilmu Pertanian. Vol 8 (2) Hlm 85-104. [Internet]. http://stppyogyakarta.ac.id/wpcontent/uplo ads/2012/04/IIP_0702_2011_Surachman_S uwardi.pdf

[UU]. Undang-Undang Nomor 11 Tahun 2009. 2009. Peraturan tentang Kesejahteraan Sosial. [Internet]. [Diunduh 2 Desember 2014]. Dapat diunduh di: http://www.itjen.depkes.go.id/-

public/upload/unit/pst/files/Undangundang/U U_No_11_Th_2009 ttg_Kesejahteraan_Sos ial.pdf

Yusdja Y dan Ilham N. 2006. Arah Kebijakan Pembangunan Peternakan Rakyat. Analisis Kebijakan Pertanian. [Internet]. [Diunduh 1 Desember 2014]. Vol 4 (1) Maret. Hlm: 1838. Dapat diunduh dari: http://blogs.unpad.ac.id/dwicipto/files/2009/09/penun-jang-3.pdf 
Jayanti \& Sjaf / JSKPM 1(3): 299-316 